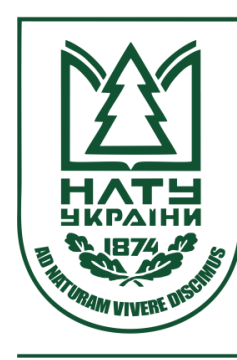

Науковий вісник НЛТУ України Scientific Bulletin of UNFU http://nv.nltu.edu.ua

https://doi.org/10.36930/40291017

$@ \bowtie$ Correspondence author

Article received 26.10.2019 p.

Article accepted 26.12.2019 p.

I. F. Kolyadzhin

УДК 630*35

I. Ф. Коляджин

Прикарпатський національний університет ім. Василя Стефаника, м. Івано-Франківськ, Украйна

\title{
ДЕЯКІ ОСОБЛИВОСТІ СУЧАСНОЇ СИСТЕМИ ЛІСІВНИЧОЇ ОСВІТИ
}

Викладено окремі аспекти сучасної системи лісівничої освіти в контексті світових трендів. Метою огляду є узагальнення інформації з питань реформування лісівничої освіти вищої школи України. Перспективними напрямами їі є подальша екологізація знань для реалізації парадигми сталого розвитку, а також послідовне впровадження системи профільних навичок і знань компетентності, креативності, синтезу формальної та неформальної освіти від компетентнісної до ціннісної системи навчання. Необхідні подальші напрацювання у системі лісівничої освіти задля впровадження сучасних технологій навчання, зокрема з фундаментальних лісівничих наук, та запровадження мобільної платформи лісівничих дисциплін, аналогічної Рrоmetheus. Доцільно опрацювати більш модифіковані програми формальної і неформальної освіти задля підсилення універсальності вищої лісової освіти, в якій поєднуються біологічна, інвайроментальна, технічна та економічна складові. Позитивний досвід реформування вищої лісівничої та екологічної освіти в європейських країнах базувався на вдосконаленні організації, структуруванні, фінансуванні, акредитації вищих навчальних закладів, упровадженні нових форм навчання та надання можливості академічної мобільності студентам і викладачам.

Ключові слова: екологізація освіти; стандарти вищої освіти; екологічна компетентність; кадрове забезпечення сталого розвитку.

Вступ. У різних країнах світу існують певні відмінності в підходах до системи і змісту лісівничої підготовки в закладах різного рівня. Ухвалення Закону України "Про вищу освіту" (2014р.) уможливило осучаснене бачення розвитку університетської освіти країни (Education, 2019). Основними завданнями вищого навчального закладу (відповідно до ст. 26) $є$ провадження на високому рівні освітньої діяльності, яка забезпечуе здобуття особами вищої освіти відповідного ступеня за обраними ними спеціальностями; участь у забезпеченні суспільного та економічного розвитку держави через формування людського капіталу; формування особистості шляхом патріотичного, правового, екологічного виховання, утвердження в учасників освітнього процесу моральних цінностей, соціальної активності, громадянської позиції та відповідальності, здорового способу життя, уміння вільно мислити та самоорганізовуватися в сучасних умовах. Для університетів одним з основних завдань $€$ провадження наукової діяльності шляхом проведення наукових досліджень і забезпечення творчої діяльності учасників освітнього процесу, підготовки наукових кадрів вищої кваліфікації і використання отриманих результатів у освітньому процесі, а також забезпечення органічного поєднання в освітньому процесі освітньої, наукової та інноваційної діяльності (Tunytsya, et al., 2015; Education, 2019).

Автономія університету також передбачає децентралізацію процесів формування змісту навчання як засіб, який підвищує відповідальність університету, науковопедагогічних працівників та студентів за якість освіти.
Тож необхідно запровадити систему внутрішнього забезпечення якості освіти. Контроль за якістю освіти здійснюється паралельно - всередині університету і ззовні, через Національне агентство із забезпечення якості вищої освіти. Завдяки цьому для широкого загалу стануть відкриті система оцінювання знань, описи дисциплін та програм, інформація про фахові досягнення науково-педагогічних працівників університету. Ці нововведення забезпечать якість і добрі результати за умови конкуренції між вищими навчальними закладами і викладачами (конкуренція за академічну якість) (Теrentieva, 2016).

Загалом, система лісівничої освіти повинна бути готова та реагувати належно на проблеми сталості, що існують зараз та виникатимуть у майбутньому. Це потребує, окрім іншого, інтеграції освіти для сталого розвитку в навчальні програми та національні стандарти якості, а також формування відповідних системних показників, які встановлюють стандарти результатів навчання (Tunytsya, et al., 2015). Освіту для сталого розвитку розглядають як важливий чинник якості освіти і її потрібно включити до критеріїв оцінки якості національної системи освіти. На потребі екологізації освіти з метою підготовки фахівців для сталого розвитку наголошено також в інших важливих документах (Kostetska, 2017; Bezkoshtovnyyi, 2018; Tunytsya, et al., 2015).

Мета роботи - викласти сутність світових трендів у лісівничій освіті: екологізації- як інноваційного освітньо-виховного процесу, а також впровадження системи профільних навичок і знань, якими повинен воло-

\section{Інформація про авторів:}

Коляджин Iгор Федорович, канд. с.-г. наук, доцент, кафедра лісознавства. Email: broshniw.lis@gmail.com

Цитування за ДСТУ: Коляджин І. Ф. Деякі особливості сучасної системи лісівничої освіти. Науковий вісник НлтУ України. 2019, т. 29, № 10. С. 85-88.

Citation APA: Kolyadzhin, I. F. (2019). Some aspects of the modern system of forestry education. Scientific Bulletin of UNFU, 29(10), 85-88. https://doi.org/10.36930/40291017 
діти спеціаліст галузі, а також окреслити сучасні вимоги світової спільноти до забезпечення підготовки фахівців для сталого розвитку та шляхи їх імплементації на національному рівні на базі здобутків ВНЗ України.

Результати дослідження та їх обговорення. Лісівнича освіта в Україні останніми роками зазнала значної модернізації. Передовсім це стосується нових технологій навчання і посилення екологізації освіти всіх рівнів. У цьому напрямі певні напрацювання мають університети, які є профільними в лісівничій освіті та науці. Так, Національний лісотехнічний університет України, який працює під гаслом "Ad naturam vivere discimus" ("Вчимося жити в гармонії з природою"), започаткував ще 30 років тому комплексну програму екологізації підготовки фахівців різних галузей знань і спеціальностей, запровадження нових сучасних магістерських програм підготовки фахівців 3 екологобезпечних та ресурсоощадних технологій, $з$ економіки довкілля і природних ресурсів, а також проведення системних наукових досліджень, виховних і просвітницьких заходів, спрямованих на формування екологічної свідомості та екологічної культури студентів (Tunytsya, et al., 2015).

Екологізація освіти передбачає наповнення екологічною компонентою змісту навчальних програм підготовки фахівців з усіх спеціальностей. Вона повинна стати ключовим чинником творення інноваційної освітньої парадигми підготовки і виховання фахівця з екологоекономічним способом мислення. Йдеться про формування нової людини, яка відповідальна перед суспільством за результати своєї діяльності, спроможної забезпечувати сталий розвиток суспільства, жити та працювати в гармонії $з$ природою (Tunytsya, et al., 2015). Цей напрям потрібно і надалі розвивати задля формування фахівців з активною громадянською позицією.

Надалі для вирішення проблем відносин "людина ліс - лісівництво" поряд із базовими предметами, які вивчають на лісогосподарських факультетах, необхідно приділяти увагу фундаментальним предметам, які розширюють світогляд студентів, зокрема пов'язаних із навколишнім середовищем, урегулюванням інтересів збереження природних екосистем і лісового господарства, а також із лісовим і природоохоронним законодавством, лісовою політикою, туризмом, створенням і захистом насаджень населених пунктів, інформатикою, ергономікою, гігієною безпеки тощо.

Водночас необхідно модернізувати саму систему освіти у вищій школі. Перспективними напрямами цього процесу є такі: вдосконалення навичок компетентності, формування світогляду студента, навчання креативності, поглиблений синтез формальної та неформальної освіти, покращена візуалізація викладання (Zibtsev, 2014). $€$ базові фундаментальні знання, а є компетенції, потрібні людині для життя, Їхня пропорція, за даними сучасних досліджень, які проведені в європейських університетах, повинна бути співрозмірна і сягати співвідношення 50:50 (Egetenmeyer, \& Strauch, 2008). Базовими сьогодні $є$ комп'ютерні знання, знання мов, бізнесу, вміння спілкуватися, загальна ерудиція. До компетенцій, які потрібно сформувати, належать позитивне, креативне, критичне мислення, цілеспрямованість, робота в команді тощо. При цьому необхідні добрі знання 3 фундаментальних наук. Стосовно лісотехнічної освіти це знання екології, біології та інших природничих наук.
За даними дослідження Всесвітнього економічного форуму, до 2020 р. креативність стане однією із найважливіших навичок, яку роботодавці цінуватимуть у своїх працівниках. Тому серед нових вимог до університетів - стати креативною навчальною спільнотою. На це наголошує і Лісабонська декларація про європейські університети. Світ швидко змінюється, і це актуальне питання: чому і як навчати студентів сьогодні? Не можна їм просто давати інформацію. I це добре, що $\mathrm{MOH}$ говорить про компетентнісне навчання. Студентів треба навчати дискутувати, критично мислити. Скандинавські країни вже перейшли від компетентнісного до ціннісного навчання (Kostetska, 2017; Bezkoshtovnyyi, 2018).

Необхідно ознайомити студентів із сучасними аспектами управління лісовим господарством, які не входять до традиційних програм, зокрема стосовно впливу клімату на ліс і реакції лісових екосистем, адаптації лісів і лісового сектора до змін клімату та пом'якшення наслідків можливого впливу змін клімату на ліси та лісове господарство, прийняття логічних рішень щодо ціноутворення під час заготівлі й транспортування деревини, використання дистанційного зондування та ГІСтехнологій зі способів вирощування і формування лісу, оцінювання й моніторингу біорізноманіття лісових територій для визначення їх охоронного статусу; використання біомаси та біоенергії лісу.

Суть освіти - у формуванні світогляду студента. Тому необхідно спрямувати зусилля не на веденні конспектів з датами і термінами, а на відкритій дискусії, де аудиторія часто стає майданчиком для відкритої комунікації та обміну думками, що збагачує світогляд студента. Сучасні викладачі намагаються знайти індивідуальний підхід до кожного, в такий спосіб створюючи оптимальні умови для прогресу студентів. Виховання молодого покоління, здатного гармонійно співіснувати 3 природою, раціонально використовувати і відтворювати її багатства, психологічно готового оберігати природу і $\epsilon$ екологічним імперативом лісівника-еколога (Tunytsya, et al., 2015). Це потребує переорієнтування екологічного виховання на можливість здійснювати випереджувальну підготовку людини до переходу на стратегію сталого розвитку. Сталий розвиток $є$ новим принципом людського спільного життя: майбутні покоління повинні мати ті самі ресурсні можливості, що мають і нині існуючі. Отже, суспільство висуває потребу в компетентній особистості, яка на основі самостійного критичного мислення і відповідальності буде готовою і здатною не лише визначати екологічні проблеми, знаходити раціональні шляхи вирішення їх, а й запобігати виникненню останніх (Nurzhynska, 2018). У курсі навчальних програм університетів лісівничого профілю варто передбачити читання лекцій і практичної підготовки 3 охорони природних екосистем різного рівня, превентивних заходів 3 їх збереження і охорони внаслідок зростаючого антропогенного впливу, технологій раціонального і природоощадного лісокористування і сучасних природоохоронних способів заготівлі деревини.

Для роботодавців найбільш важливими є знання та вміння. Найціннішими універсальними навичками є: багатозадачність, критичне мислення і далекоглядність, креативність, вміння нестандартно мислити, вміння вирішувати комплексні завдання, прагнення до вдосконалення і готовність навчатися, розвинені соціальні навички, вміння працювати в команді, навички самоорга- 
нізації, уміння ставити цілі і досягати їх (Nurzhynska, 2018; Toffler, 2000). Чи не найважливіша навичка в сучасних умовах - це вміння виконувати безліч різноманітних завдань у короткі терміни. Більшість роботодавців дуже цінують співробітників, які $є$ універсальними, можуть одночасно виконувати різні напрями роботи i при цьому працювати ефективно. Розвинути критичність мислення допомагає начитаність, допитливість, вміння спостерігати і помічати причинно-наслідкові зв'язки. Роботодавці найбільший акцент роблять якраз на здатності працівників бути залученими в колектив, поважати інших. Інновації з'являються не від того, що хтось щось зробив, а від того, що він зміг зробити щось спільно $з$ іншими та 3 думкою про них. Повна компетентність студента і майбутнього фахівця - це ментальність, ставлення до інших людей, груп, установ, проблем, поведінки чи символів. Тобто це не лише вміння бути відкритим, поважати інших, мислити глобально, це ще й вищий рівень - цінності. Вони охоплюють розуміння понять людської гідності, культурного різноманіття тощо.

Спеціальність лісівника $є$ багатопрофільною і багатьом фахівцям доводиться виконувати складні різнопланові завдання: вирощування лісів і посадкового матеріалу, охорони їх від пожеж, захист від шкідників і хвороб, методи і способи створення лісових культур тощо. Уміння орієнтуватися у безлічі питань і напрямів дуже цінується роботодавцями. Вони звертають увагу на соціальні навички майбутнього співробітника, адаптивність у поведінці, комунікативні здібності, вміння налагодити контакт із різними людьми і підтримувати стосунки, а також залагоджувати розбіжності і конфлікти. Також важливим є вміння вести дискусії, приймати командні рішення та брати відповідальність за загальний результат. На будь-якому лісогосподарському підприємстві цінують тих співробітників, які не перестають вчитися, проходити різні курси й освоювати нові навички, які можна використати в роботі. "Неписьменними XXI століття будуть не ті, хто не вміє читати й писати, а ті, хто не може вчитися і переучуватися" - такий прогноз Елвіна Тоффлера, одного з авторів концепції "Інформаційної цивілізації" цілком слушний і щодо фаху лісівника (Toffler, 2000).

Правильно розподілити час на виконання завдань, проконтролювати питання, пов'язані з іншими співробітниками і відділами - все це потребує навичок самоорганізації. Результативність співробітників багато в чому залежить від уміння ставити правильні цілі та звичайно ж їх досягати. Саме тому вищі навчальні заклади повинні спрямовувати навчання студентів не лише на засвоєння знань, але й на досягнення вмінь їх застосовувати. Навчання під конкретний запит та поєднання навичок з різних галузей нині більш у тренді, ніж вузька спеціалізація майже 3 пелюшок. Відомий афоризм: "Наука про навчання дуже багато досліджувала навчання і дуже мало відкрила". Але одне вона встановила точно - ефективним є лише активне навчання. Більше того, пасивного навчання в принципі не буває. Пасивне навчання - це не навчання, а його імітація. Масовий онлайн-курс - це лише перший крок (хоч і примітивний). Вони вже не пасивні за визначенням - в них, окрім відео-лекцій, є обов'язкові завдання, форуми, дискусійні обговорення.
Наступний крок - мобайл, мобільні додатки, які вже запустили більшість мобільних платформ, зокрема й Prometheus. Далі - віртуальна реальність, можливість переглядати інтерактивні схеми, схеми процесів. Програма або комбінація програми і людини зможуть рухатися в темпі, який зручний для студента (повільніший чи швидший) і завжди підтримуючи оптимальний рівень зацікавленості. Стосовно лісівничої освіти - це вміння осягнути процес ведення лісового господарства не за окремими складовими, а в комплексі виробничих завдань і їх ефективної реалізації стосовно сучасних умов і перспектив. Мобільна платформа лісівничих дисциплін, аналогічна Prometheus, в Україні поки що тільки опрацьовується і може виявитися доцільною та ефективною.

Формальна та неформальна освіта повинні працювати у синтезі, прикладом цього є розроблена Європейською Комісією єдина Програма навчання протягом життя (Lifelong Learning Programme), яка об'єднує різні освітні й навчальні ініціативи (Egetenmeyer, \& Strauch, 2008). Сюди входить і неформальна освіта. Дослідники Національного інституту стратегічних досліджень стверджують, що цей вид навчання допомагає різноманітним групам населення адаптуватися до мінливих умов життя. Неформальну освіту інтегрують у формальну, щоб краще врахувати прагнення, потреби та очікування різних навчальних груп. В Україні сьогодні немає встановлених стандартів неформальної освіти, однак є декілька платформ, які дають змогу неформально навчатися, а також створювати свої курси. Коли принцип пожиттєвого навчання стане справді інтегральним, тоді побачимо набагато більш гармонійну освітню систему. Для підготовки фахівців з лісового і мисливського господарства таку програму поки що не розроблено, хоча перспективність і доцільність ії очевидна.

Студенти надають перевагу відеолекціям, навіть якщо заняття 3 курсу проводять в аудиторії. Дослідники з Лондонського Королівського коледжу виявили, що можливість подивитися лекції з курсу в Інтернеті призвело до того, що вдвічі більше студентів перестали ходити на заняття. Це спричинило значне зниження рівня успішності. Тому презентації досі залишаються хорошим способом донесення інформації для студентів. Це зокрема стосується і лекцій з охорони тваринного і рослинного світу (Milburn, 2018). Вони досить добре опрацьовані в навчальних закладах України, але потребують подальшого вдосконалення у плані ціннісного підходу в навчанні.

Позитивний досвід реформування вищої лісівничої і екологічної освіти в Німеччині в межах створення єдиного європейського освітнього простору базувався на: вдосконаленні організації, структуруванні, фінансуванні, акредитації вищих навчальних закладів, упровадженні нових форм навчання та надання можливості академічної мобільності студентам і викладачам. Основою цього стало розроблення механізмів інтеграційної політики в галузі вищої європейської лісівничої освіти. Змістовий аспект при цьому мыстить традиційні освітянські підходи: оновлення навчальних планів і програм, модернізацію ефективних форм і методів навчання тощо (Kostetska, 2017).

Універсальність вищої лісової освіти, в якій поєднуються біологічна, технічна та економічна складові, зу- 
мовили зростання її популярності в Україні та кількості навчальних закладів, які отримали ліцензію на підготовку фахівців ОКР бакалавр та магістр за напрямом "Лісове і садово-паркове господарство". Загалом навчальні програми на факультетах спрямовані в міру можливостей на теоретичне та практичне навчання студентів як існуючим на лісових підприємствах видів робіт, так і найкращому світовому досвіду у веденні лісового господарства. Проте, внаслідок відірваності в багатьох випадках науки від виробництва, вмотивованість значної частини студентів у отриманні нових знань на лісових факультетах досить низька (Zibtsev, 2014). Заклади освіти розташовані по всій території України і здебільшого здійснюють підготовку майбутніх фахівців для роботи в лісовому господарстві в регіоні розташування закладу. При цьому теоретична і практична підготовка переважно враховує регіональні особливості лісів та лісового господарства головних природних зон України.

\section{Висновки:}

1. Основними напрямами вдосконалення лісівничої освіти на найближчу перспективу необхідно вважати поглиблення екологізації знань задля наповнення екологічною компонентою змісту навчальних програм підготовки фахівців 3 усіх спеціальностей та послідовне впровадження системи профільних навичок і знань компетентності, креативності, синтезу формальної та неформальної освіти від компетентнісної до ціннісної систем навчання. У цьому складному творчому процесі повинні брати консолідовану участь усі навчальні заклади, владні структури, бізнес і громадянське суспільство.

2. Для роботодавців найбільш важливими $є$ знання та вміння фахівця. Найціннішими універсальними навичками $€$ : багатозадачність, критичне мислення і далекоглядність, креативність, вміння нестандартно мислити, вміння виконувати комплексні завдання, прагнення до вдосконалення і готовність навчатися, розвинені соціальні навички, вміння працювати в команді, навички самоорганізації, уміння ставити цілі і досягати їх. Сус- пільство висуває потребу в компетентній особистості, яка на основі самостійного критичного мислення і відповідальності буде готовою і здатною не лише визначати екологічні проблеми, знаходити раціональні шляхи вирішення їх, а й запобігати виникненню останніх. Цьому повинні передувати набута система фахових знань та активна громадянська позиція лісівника-еколога.

\section{References}

Bezkoshtovnyyi. (2018). Krytychne myslennya dlya osvityan: bezkoshtovnyyi onlain-kurs. Retrieved from: https://www.prostir.ua/?news=krytychne-myslennya-dlya-osvityan-bezkoshtovnyjonlajn-kurs. [In Ukrainian].

Education. (2019). Law of Ukraine on Higher Education. Retrieved from: $\quad$ http://zakon2.rada.gov.ua/laws/show/155618/print1382613528661298. [In Ukrainian].

Egetenmeyer, R., \& Strauch, A. (2008). What's new in Europe? Recent Trends in Adult and Continuing Education. Report, 31(2), 9-17.

Kostetska, M. (2017). Development of higher European education in education dimension. Molod i rynok, 3(146), 137-142. [In Ukrainian].

Milburn, R. (2018). Could wildlife hold the key to rebuilding countries post-war? Retrieved from: https:/www.kcl.ac.uk/news/spotlight-article.aspx?id=8842ee54-fd05-4f6e-ba35-75557bcaf3a1

Nurzhynska, A. (2018). 10 Trends That Will Change Higher Education. Ukrainska pravda, 8.07.2018. [In Ukrainian]. Retrieved from: https:/life.pravda.com.ua/society/2018/07/8/232005/

Toffler, E. (2000). Third wave. Kyiv: Publishing House "Vsesvit", 480 p. [In Ukrainian].

Tunytsya, Yu. Yu., Adamovsky, M. G., Borys, M. M., Kraevskyi, S. N., \& Магаzynshchykova, I. P. (2015). Ecologization of education as a key factor in the training of specialists for sustainable development. Scientific Bulletin of UNFU, 25(10), 348-356. https://doi.org/10.15421/40251053

Terentieva, N. O. (2016). Trends in the development of university education in Ukraine: the theoretical basis for the definition of new vectors. Bulletin of Taras Shevchenko National University of Kyiv. Pedagogy, 2(4), 69-76. [In Ukrainian].

Zibtsev, S. V. (2014). Forestry education in Ukraine. FAO Consolidation of Forest Policy of Ukraine. Retrieved from: https://www.lisportal.org.ua/25071/. [In Ukrainian].

I. F. Kolyadzhin

Vasyl Stefanyk Precarpathian National University, Ivano-Frankivsk, Ukraine

\section{SOME ASPECTS OF THE MODERN SYSTEM OF FORESTRY EDUCATION}

The article outlines some aspects of the modern system of forestry education in the context of world trends. The purpose of the research is to summarize information on the reform of the forestry education of the higher school of Ukraine. Its promising directions are the further ecologization of knowledge for the implementation of the paradigm of sustainable development, as well as the consistent implementation of the system of profile skills and knowledge of competence, creativity, and the synthesis of formal and informal education from the competent to the value system of education. Further development in the forestry education system is needed to introduce modern training technologies, in particular, from basic forestry sciences and the introduction of a mobile platform for forestry disciplines similar to Prometheus. It is advisable to work out more modified programs of formal and informal education in order to enhance the universality of higher forest education, which combines biological, invariant, technical and economic components. The positive experience of reforming higher forestry and environmental education in European countries was based on improved organization, structuring, financing, accreditation of higher education institutions, the introduction of new forms of education and the provision of academic mobility for students and professors.

Keywords: ecologization of education; standards of higher education; environmental expertise; staffing for sustainable development. 